\title{
Design, manufacture and test of a dental camera using fluorescence technique
}

\author{
Pham Thi Hai Mien, Duong Ngoc Khanh Vy, \\ Nguyen Tien Dat, Huynh Thi Hoang Vy.
}

\begin{abstract}
Dental caries is a major oral health problem in most industrialised countries and is still a major cause of tooth loss. The early diagnostics of caries is of great importance for children and adults to facilitate the treatment and prevention of the diseases. In this study, a fluorescence camera was designed and manufactured for this purpose. This device includes a 380-nm LED, which stimulates porphyrins - metabolic products of the life cycle of caries-inducing bacteria to emit fluorescence, and a compact camera recording fluorescence images in real time. The device is connected to computer via usb cable. An archiving software helps save shots as image or video. The weight and size of this device are suitable for the visual inspection in oral cavity and can be used in daily dental practice. The test results showed that this fluorescence camera can detect some types of carious lesions including dental plaque, dental caries, hidden caries and early caries. Besides, this tool has a number of advantages such as noninvasiveness, safety (non-ionizing radiation), mobility, rapid test time, and economical..
\end{abstract}

Index Terms-Camera, dental caries, fluorescence, LED.

Manuscript Received on July 13 ${ }^{\text {th }}$, 2016. Manuscript Revised December 06 ${ }^{\text {th }}, 2016$.

This research is funded by Ho Chi Minh City University of Technology - VNU-HCM under grant number T-KHUD-201736.

Pham Thi Hai Mien is with Ho Chi Minh City University of Technology - VNU-HCM, Ho Chi Minh City, Viet Nam (e-mail: phamhaimien@hcmut.com.vn).

Nguyen Tien Dat is with Ho Chi Minh City University of Technology - VNU-HCM, Ho Chi Minh City, Viet Nam (e-mail: ntdat.211@gmail.com).

Duong Ngoc Khanh Vy is with Ho Chi Minh City University of Technology - VNU-HCM, Ho Chi Minh City, Viet Nam (email: dnkvy95@gmail.com).

Huynh Thi Hoang Vy is with Ho Chi Minh City University of Technology - VNU-HCM, Ho Chi Minh City, Viet Nam (email:k1304947@hcmut.com.vn).

\section{INTRODUCTION}

Dental caries is the most prevalent of the oral diseases worldwide. Traditionally, dental professionals rely mostly on subjective interpretation of clinical-tactile inspection, aided by dental radiography for caries detection [1]. However, these methods often show low sensitivity, and can be difficult to objectively measure mineral loss, meaning that a large number of lesions may be missed [2, 3]. Subjective interpretation can also lead to widely varying diagnoses depending on the test conditions and examiner experience [4]. Furthermore, because of the possible hazardous effects of ionizing radiation, X-ray based methods can be unsuitable for patient groups such as children and pregnant women, the subjective judgement of this method is neither quantitative nor sensitive enough to detect early enamel caries lesions [5].

Today, the demand for accuracy and early diagnosis of caries is higher than before. The lesion needs to be assessed as to whether the caries is limited to enamel or if it has progressed to dentin. A determination of whether the lesion is cavitated needs to be made since cavitated lesions continue to trap bacterial plaque and need to be restored. So that several new diagnostic tools are constantly being investigated and obtain promising results. One of the newly developed diagnostic procedures employs fluorescence diagnostics. Quantitative light-induced fluorescence (QLF) is based on the autofluorescence of teeth. When teeth are illuminated with high intensity blue light, they will start to emit light in the green part of the spectrum. The fluorescence of the dental material has a direct relation with the mineral content of the enamel [6]. It is important to emphasize that QLF can be influenced by some factors, such as stains, dental plaque, dental fluorosis or hypomineralization. Another fluorescence technique - laser-induced fluorescence is based on the quantification of emitted fluorescence from organic components of 
dental tissues when excited by a $655 \mathrm{~nm}$ laser diode located on the red range from the visible spectrum. The laser is able to excite either the hard dental tissue, resulting in the tissue autofluorescence, or fluorophores present in the caries lesions. This device has shown good results in the detection of occlusal caries, however, it might not be used as the only method for treatment decision-making process [7]. The other investigators have shown that under UVA light (near ultraviolet) sound teeth emit blue - green color, while caries teeth emit the red fluorescence [8-14]. Based on the difference in the color of the teeth fluorescence caries lesions can be detected.

Fluorescence technique using $380-\mathrm{nm}$ light is non-destructive, non-invasive, and non-ionizing radiation. This method also shows high sensitivity in the detection of early demineralization and early dental caries lesion. In this paper, the fluorescence technique was applied to design and create a device model for detecting the appearance of bacteria causing caries. The in vitro testing method was conducted to analyze and evaluate the device.

\section{MATERIALS AND METHODS}

\subsection{LEDs}

The device for detection of dental caries is a system that consists of two LEDs: one white LED PLCC-6 Oval for the general examination, one SMD 380-nm LED with 1W-power for exciting teeth fluorescence. The field of view of white LED must provide the full overview of the oral cavity in the inspection process. For that request, a white LED with three integrated diodes was used.

With 380-nm LED, the wavelength and power play aimportant role in stimulating fluorescence. According to the research results of the thesis of Duong Van Hung and Nguyen Van Tuan [11], the UVA or violet light ( $365 \mathrm{~nm}, 380 \mathrm{~nm}$ and $405 \mathrm{~nm})$ are suitable for exciting teeth fluorescence. The fluorescence images stimulated by $380 \mathrm{~nm}$ wavelength hadhigh contrast between the blue and red fluorescence better than by $365 \mathrm{~nm}$ and 405 $\mathrm{nm}$. With $1 \mathrm{~W}$ power LED the fluorescence intensity of all obtained images was available for the unaided eye observation. Therefore, the $380-\mathrm{nm}$ LED with $1 \mathrm{~W}$ power was chosen in this study.

\subsection{Source and stable voltage ciruit}

Two LEDs are provided with 3,3 V DC power from batteries or USB port of the computer through a stable voltage circuit and source selector switch. The power of LEDs is controlled by hand in a flexible manner. The stable voltage circuit receives input from the battery or the computer and the output voltage is $3,3 \mathrm{~V}$ to match the performance parameters of the LEDs.

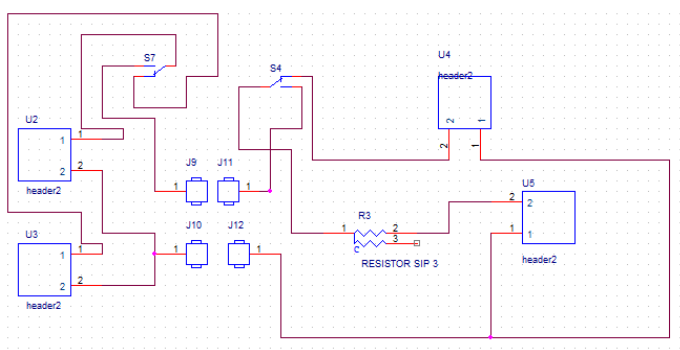

Figure 1. Stable voltage ciruit

\subsection{Camera}

The recorded image can be directly observed with the naked eye or through the camera. Due to the poorness of the lightand space condition in the oral cavity the camera should have a short focal length $\sim 1 \mathrm{~cm}$ and high sensitive $\sim 5 \mathrm{Mps}$ to appropriate to record fluorescence image of the teeth. This camera is connected to computer with usb cable 2.0.

\subsection{Filters}

The light emitted from the 380 -nm LED is not monochromatic with a spectrum from $370 \mathrm{~nm}$ to $390 \mathrm{~nm}$. The edge of the LED spectrum in the visible region causes the overlap with the fluorescence spectrum of teeth. In this case, one UV bandpass filter (UG-1, Edmund Optics) was used for passing only wavelength shorter than 400 $\mathrm{nm}$ and eliminating unwanted visible light from the LED.

The 380-nm LED is arranged close to the camera so the LED light can scatter and decrease the quality of fluorescence images recorded by camera. Therefore, a JB490 filter was placed in front of the camera to block the scattered light from LED and pass the fluorescence signals from teeth.

\subsection{Radiator for LEDs}

The heat emitted in the working process of device is mainly due to the LEDs. The temperature does not affect the course of the survey and the quanlity of fluorescence images but shortens the life span of LEDs. A radiator base plate for LEDs was designed and placed at the back of the white and 380-nm LEDs.

\section{RESULTS AND DISCUSSION}

\subsection{Design - build process}

The aim ofthis study was to design a portable fluorescence camera forobservation in the oral 
cavity. Therefore, the device must be easy to use: the camera header is small for comfortable manipulation in the visual inspection, the body of device should be light and fit for hand, and the LED controler in a convenient location for controlling LED intensity. The device was modeled by SolidWorks software and builded by 3D printing.

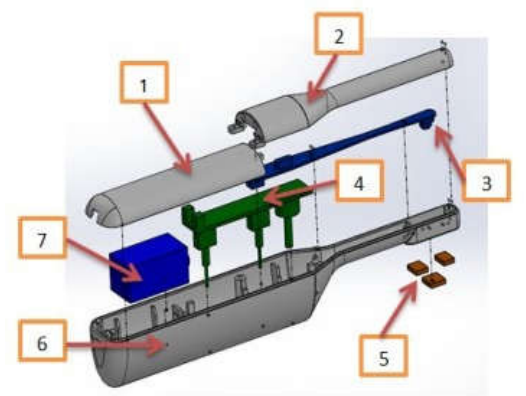

Figure 2. Device structure: 1 - Battery cover, 2 - Upper body, 3 - Camera, 4 - Circuit, 5 - Filters, 6 - Lower body, 7 Battery
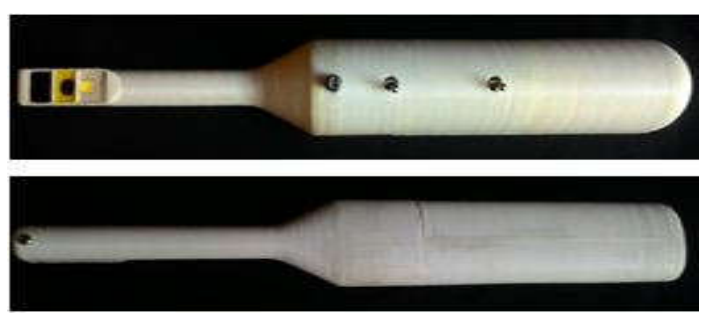

Figure 3. Fluorescence camera

\subsection{Safety equipment}

In any electrical and radiation equipment, the most important requirement is safeness. By using low voltage (under 5V), and plastic materialfordevicecasing, dental caries detection device is perfectly safe. Besides, the light-emitting diodes operating in the near ultraviolet (UVA), the lowest photon energy of the three ultraviolet wavebands, has virtually no effect on human tissue with short-term exposures [15]. In this research, we had tested the power LEDs emitting 380-nm peak in exciting human tissue in 1 minute and below.

\subsection{Test of device}

\subsubsection{Tooth samples}

The experiments were made on extracted teeth (in vitro) and in vivo. All samples, without dental restorations to ensure the presence of questionable occlusal caries, were classified according to the visual criteria of the International Caries Detection \& Assessment System (ICDAS) [16].

\subsubsection{The results of device testing}

All samples of thesound and lesion teeth were observed under white light and 380-nm LED of designed fluorescence camera.
Fig. 4 shows a sound teeth specimen (sample 1). Under UVA excitation, as can be seen in Fig. 4B, this sample emitted the blue-green color on a white background. As known that the healthy teeth emits blue or green fluorescence when irradiated with near ultraviolet or violet-blue light,respectively [17-18]. In this work the 380-nm LED emitting band from $370 \mathrm{~nm}$ to $390 \mathrm{~nm}$ was used that was capable of stimulating a broad emission band in the visible region with maximum located at blue green wavelengths. For many years, researchers have studied the origin of natural fluorescence in dental hard tissue. While the chromophores of fluorescence at 350-400 nm (in UVA wavelength) with excitation wavelength shorter than $300-325$ $\mathrm{nm}$ have been identified (traces of trypthophan and hydroxypyridinium [19], the other fluorescence colors in visible region remain unidentified. Thus, the determination of fluorophores emitting blue green color in sound teeth requires further investigation.

Besides blue-green fluorescence observed in sound teeth, the red color appeared in the samples with different types of lesions. Sample 2 with dental calculus is presented in Fig. 5, where the calculus illuminated the strong red fluorescence. Calculus is a form of hardened dental plaque. It is caused by precipitation of minerals from saliva and gingival crevicular fluid in plaque on the teeth. There are about 1,000 out of the 25,000 species of bacteria that are involved with the formation of dental plaque, but microorganisms that form the plaque are mainly Streptococcus mutans and anaerobes, with the composition varying by location in the mouth [10]. It has long been recognized that the bacteria Streptococcus mutans produces special metabolites called porphyrins. Porphyrins are the native fluorophores that strongly emits red light under UVA excitation. This fluorescence is detected in some studies [11-13, 2021]. The denser the bacterial colonization, the more intense the red fluorescent signal will be.

The red fluorescence was also found in more advanced lesions (dentinal lesions) as can be seen in Fig. 6 (sample 3). The caries in of this sample was scored as International Caries Detection \& Assessment System Code 6 (extensive distinct cavity with visible dentin). Dental caries, also known as tooth decay, cavities, or caries, is breakdown of teeth due to the activities of bacteria. The mouth contains a wide variety of oral bacteria, but only a few specific species of bacteria are believed to cause dental caries: Streptococcus mutans and Lactobacillus species among them. These organisms break down the hard tissues of the teeth (enamel, dentin and cementum) by making 
acid from food debris on the tooth surface [8]. As mentioned above, the bacteria Streptococcus mutans produces porphyrins, which have red fluorescence observed in Fig. 6.
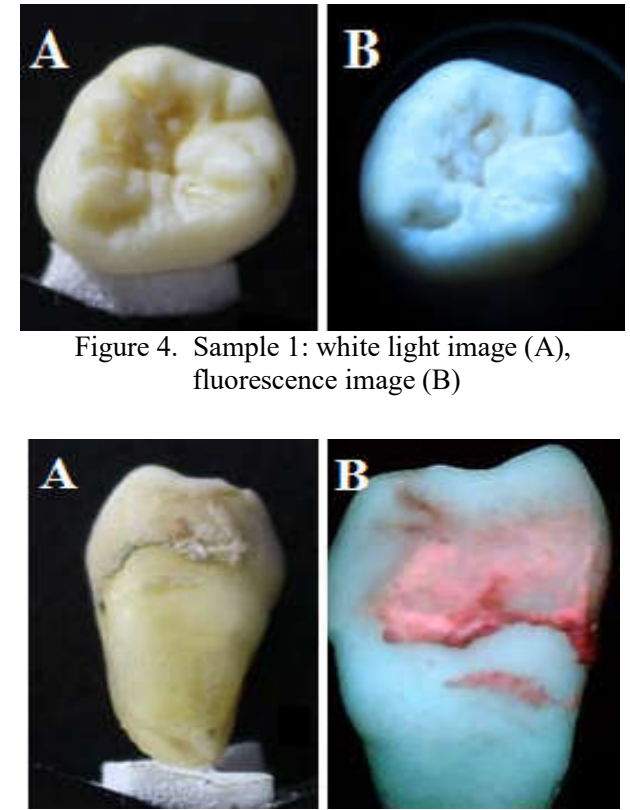

Figure 5. Sample 2: white light image (A), fluorescence image (B)
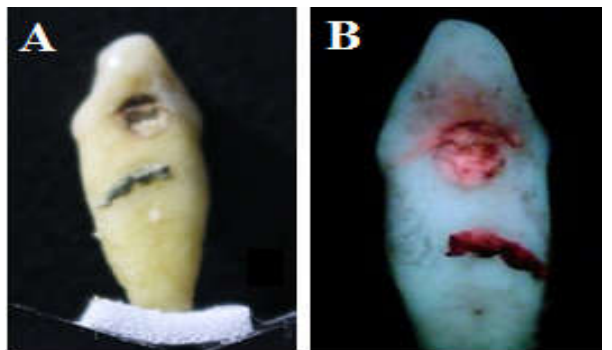

Figure 6. Sample 3: white light image (A), fluorescence image (B)
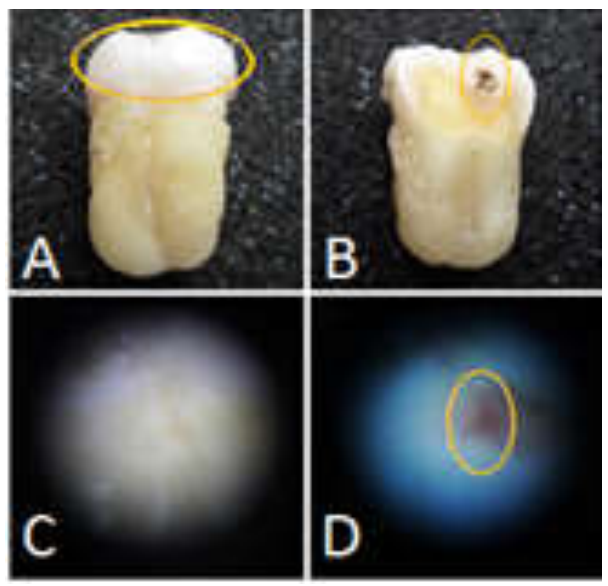

Figure 7. Sample 4: white light image before and after grinding (A, B), magnified white light and fluorescence images before grinding $(\mathrm{C}, \mathrm{D})$
However, the caries expression is not always cavitated as in the case of sample 3 . The base of a pit or fissure, which is usually the most susceptible to acid attack, often exhibits caries without any visual occlusal evidence other than stain. For example, Fig. 7A presents sample 4 scored as International Caries Detection \& Assessment System Code 0 (sound tooth). No mark of caries of this sample was found in lit room with normal white light illumination. However under UVA stimulation a small red spot, with careful attention, was caught. This spot was magnified 10 times for more detailed observation (Fig. 7D) by using a 10xmagnification multiple lens system. Doubting about the presence of a caries hiding under the enamel layer at an early stage, this area was ground from the surface to the dentin layer until the cavity was appeared (Fig. 7B). The result showed not an initial caries but a distinct cavity in the dentin layer.

The question is "Where is this caries cavity from"? Note that the enamel layer (thickness 1-3 $\mathrm{mm}$ ) is a filtering membrane allowing the transit of substances from the exterior to the interior, and vice versa. These zones allow the flow of acids from bacterial plaque, giving rise to disintegration of the organic material and posteriorly conditioning demineralization of the inorganic component-thus supporting the proteolysis-chelation theory of dental caries. These enamel areas with disintegration of the organic material, and the large structural defects such as cracks, which are rich in organic material, can facilitate the penetration of bacteria into deep areas of the enamel, without the existence of superficial cavitation [22].

The next question is "How can the excited light penetrate into the dentin layerat the depth of about 1-2 $\mathrm{mm}$, and on the other hand, the emission light escape from the tooth surface?". In the visible region, dentin and enamel weakly absorb light and light scattering plays an important role in determining the deposited energy distribution in the tissue [23]. From the tooth surface to the end of enamel layer, the photon density slowly decreases. The fluence at the end of enamel layer is over $95 \%$ of the value on the surface. The photons are almost completely absorbed at the depth of $3.7 \mathrm{~mm}$. In the case of sample 4, the caries was found at the depth of 1-2 mm. At this depth, the excited light can completely penetrate into the carious area for stimulating, and vice versa, the emission light can escape to the surface for observing.

The other interesting tooth (sample 5), presented in Fig. 8, need to be attended. For this sample, in white lighting condition we can see the tooth surface without any damage or plaque, but there was a brownish-yellow area circled in Fig. 8A. 
When stimulated by $380 \mathrm{~nm}$ LED this area showed the reddish color. Brown spots on teeth could be stains, enamel demineralization or they could be a symptom of tooth decay at the early stage. The lesion itself may first become noticeable as a dark spot or blemish that grows in size over time (typically months to years), frequently involving obvious tooth destruction. In this case, reddish color of brown area under $380 \mathrm{~nm}$ demonstrates the presence of bacteria, so the symptom of early caries.

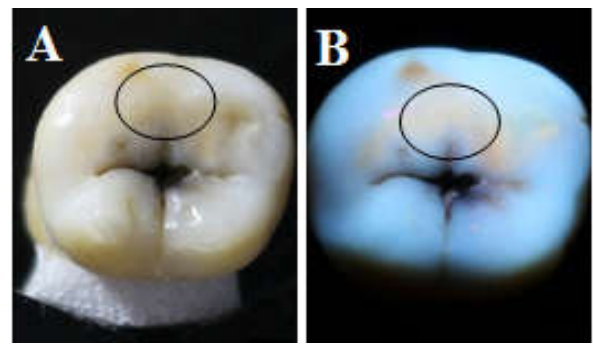

Figure 8. Sample 5: white light image (A), fluorescence image (B)

\section{CONCLUSION}

Many studies have shown that fluorescence property of sound teeth was different from of lesion teeth. Based on the difference in the color of the teeth fluorescence caries lesions can be detected. The aim of the present research was to design and manufacture a portable device for early diagnosis of dental caries using fluorescence imaging techniques, with small size and can be easily used in oral cavity. This device was used to investigate the fluorescence property of sound and lesion teeth. The test results showed that fluorescence images can give interesting information about hidden caries and caries at the early stage. At this time it is maybe too early to base solely on this diagnostic technology, but it shows the possibility to apply fluorescence technique in the development of a specificity and sensitivity dental screening tool without the use of ionizing radiation, and owning a number of advantages such as safety, mobility, low cost and rapid test time.

\section{REFERENCES}

[1]. Selwitz RH, Ismail AI, Pitts NB, Dental caries. Jacksonville, FL, USA: Lancet, 2007, pp. 51-59.

[2]. Bader JD, Shugars DA, Bonito AJ, A systematic review of the performance of methods for identifying carious lesions. Rockville, MD, USA: J Public Health Dent, 2002, pp. 201-213.

[3]. Heinrich-Weltzien R, Kuhnisch J, Ifland S, Tranaeus S, Angmar-Mansson B, Stober L. Detection of initial caries lesions on smooth surfaces by quantitative light-induced fluorescence and isual examination: an in vivo comparison. Singapore: Eur J Oral Sci, 2005, 113, pp. 494-98

[4]. Altman DG, Bland JM. Diagnostic tests. 1: Sensitivity and specificity. England: Br Med J, 1994, pp. 1552.

[5]. Buhler CM, Ngaotheppitak P, Fried D. Imaging of occlusal dental caries (decay) with near-IR light at 1310$\mathrm{nm}$. San Francisco, CA, USA: Optics Express, 2005, pp. 573-582.

[6]. A. Pretty, P. W. Smith, W. M. Edgar and S. M. Higham. Detection of in- vitro demineralization adjacent to restorations using quantative light induced fluorescence. UK: Dent Mater 19, 2003, pp. 368-374.

[7]. M. R. Alammari, P. W. Smith, de Josselin de Jong E and S. M. Higham, "Quantitative light-induced uorescence: A tool for early occlusal dental caries detection and Supporting decision making in vivo," Journal of dentistry., vol. 41, pp. 127-132, 2013.

[8]. K. M. Shivakumar, "International Caries Detection and Assessment System: A new paradigm in detection of dental caries," J Conserv Dent., vol. 12, pp. 10-16, 2009.

[9]. G. N. Jenkins, The physiology and biochemistry of the mouth. UK: Blackwell Scientific - Oxford, 1978, pp. 54112 .

[10]. A.V. Sukhinina, S. A. Gonchukov and D. N. Bakhmutov, "Fluorescence Diagnostics of Periodontitis," Bulletin of the Lebedev Physics Institute., vol. 37, pp. 175-176, 2010.

[11]. Duong Phan Hung and Nguyen Van Tuan, "Design of optical system for studying emission properties of tissue", M.S. thesis, Ho Chi Minh City University of Technology - VNU-HCM., Ho Chi Minh, Viet Nam, 2014.

[12]. I., Iulian, "Early diagnosis of tooth decay using fluorescence and polarized Raman spectroscopy," Optoelectronics and Advanced Materials-Rapid Communications., vol. 3, pp. 1122-1126, 2009.

[13]. W. R. E. Laird and A. A. Grant, "Dental bacterial plaque," International Journal of Biochemistry., vol. 15, pp. 10951102, Jul. 1983.

[14]. T. S. Uzunov, T. Uzunov, R. Grozdanova and D. Kosturkov, "Diagnosis of Dentin Caries - Ultraviolet Fluorescence," ActaMedicaBulgarica., vol. 41, pp. 55-60, Feb. 2014.

[15]. J. W. Laurence and FardadShakibaie, "Ultravioletinduced fluorescence: shedding new light on dental biofilms and dental caries, " Australasian Dental Practice., vol. 18, pp. 56-60, Dec. 2007.

[16]. A. I. Ismail, "The international caries detection and asessement system (ICDAS): an intergrateed system for measuring dental caries," Community Dent Oral Epidenmiol., vol. 35, pp. 170-178, 2007.

[17]. M. L. Sinyaeva, Ad. A. Mamedov, S. Yu. Vasilchenko, A. I. Volkova and V. B. Loschenov, "Fluorescence Diagnostics in Dentistry," Laser Physics., vol. 14, pp. 1132-1140, 2004.

[18]. V. Lutskaya, N. V. Novak and V. P. Kavetsky, "Fluorescence of dental hard tissue and restorative materials," International dentistry-African edition., vol. 2, pp.162-168, 2012.

[19]. W. G. Armstrong and H. J. Horsley, "Isolation of fluorescent components from ox-bone human dentine and gelatin," Nature., vol. 211, p. 981, 1966.

[20]. R. Hibst and R. Paulus, "New approach on fluorescence spectroscopy for caries detection," Lasers in Dentistry V., vol. 141, pp. 141-147, 1999.

[21]. R. Hibst and R. Paulus, "Molecular basis of red excited caries fluorescence," Caries Res., vol. 34, pp. 308-367, 2000.

[22]. Camilo Abalos, Amparo Jiménez-Planas, Elena Guerrero, Manuela Herrera and Rafael Llamas, "How to Diagnose Hidden Caries? The Role of Laser Fluorescence," 
Contemporary Approach to Dental Caries. InTech China, 2012.

[23]. F. Daniel, R. E. Glena, J. D. B. Featherstone and W. Seka, "Nature of light scattering in dental enamel and dentin at visible and near-infrared wavelengths, “ Applied optics., vol. 34, pp. 1278-1285, 1995.

Pham Thi Hai Mien was born in Vietnam in 1983. She received the PhD. degree in Optics from Voronezh State University, Russian Federation, in 2011. She is the lecturer of Faculty of Applied Science, Ho Chi Minh City University of Technology - VNU-HCM, Vietnam. Her research interest includes the application of optical techniques in diagnostic imaging.

Duong Ngoc Khanh Vy was born Vietnam in 1995. She is a senior student at Ho Chi Minh University of Technology. Her research relates the application of fluorescence technique in detecting dental caries.

Nguyen Tien Dat was born in Vietnam in 1995. $\mathrm{He}$ is a senior student at Ho Chi Minh University of Technology. His research relates the application of fluorescence technique in detecting dental caries.

Huynh Thi Hoang Vy was born in Vietnam in 1995. She is a senior student at Ho Chi Minh University of Technology. Her research relates the application of fluorescence technique in detecting dental caries. 


\title{
Thiết kế, chế tạo và thử nghiệm camera nha khoa sử dụng kỹ thuật huỳnh quang
}

\author{
Phạm Thị Hải Miền, Dương Ngọc Khánh Vy, Nguyễn Tiến Đạt, \\ Hoàng Gia Cát, Huỳnh Thị Hoàng Vy
}

\begin{abstract}
Tóm tắt - Sâu răng là một vấn đề sức khỏe răng miệng chính ở hầu hết các nước trên thế giới và là nguyên nhân chính gây mất răng. Việc chẩn đoán sớm bệnh sâu răng là rất quan trọng đối với trẻ em và người lớn trong điều trị và phòng ngừa bệnh tật. Trong nghiên cứu này, một camera huỳnh quang đã được thiết kế và sản xuất cho mục đích trên. Thiết bị này bao gồm một đèn LED $380 \mathrm{~nm}$ có khả năng kích thích porphyrins (một loại sản phẩm trao đổi chất của vi khuẩn gây sâu răng) phát ra huỳnh quang, và một máy ảnh nhỏ gọn ghi hình huỳnh quang theo thời gian thực. Thiết bị được kết nối với máy tính thông qua cổng usb. Một phần mềm lưu trữ giúp lưu ảnh và video. Trọng lượng và kích thước của thiết bị phù hợp cho việc kiểm tra lâm sàng trong khoang miệng và có thể được sử dụng trong thụ̣c hành nha khoa hàng ngày. Các kết quả kiểm tra cho thấy camera huỳnh quang có thể phát hiện một số loại tổn thương bao gồm mảng bám răng, sâu răng, sâu ẩn và sâu giai đoạn sớm. Bên cạnh đó, công cụ này có một số ưu điểm như không xâm lấn, an toàn (không sử dụng bức xạ ion hóa), cơ động, thời gian thử nghiệm nhanh chóng, và giá thành thấp.
\end{abstract}

Tù̀ khóa - sâu răng, huỳnh quang, LED, camera. 